\title{
Analisis Struktur Alur dalam Cerpen di Atas Sajadah Cinta Karya Habiburrahman El Shirazy
}

\author{
Abdul Goffar $\bowtie$, Universitas PGRI Madiun \\ Aris Wuryantoro, Universitas PGRI Madiun \\ Sigit Ricahyono, Universitas PGRI Madiun \\ $\triangle$ goffara9@gmail.com
}

\begin{abstract}
Abstrak: Penelitian ini difokuskan untuk mendeskripsikan struktur alur yangterdapat dalam cerpen Di Atas Sajadah Cinta karya Habiburrahman El Shirazy dan pengimplementasian pembelajaran struktur alur terhadap mata pelajaran bahasa Indonesia di SMP/MTs Kelas IX. Penelitian ini menggunakan metode deskriptif, bentuk penelitian ini adalah kualitatif, dan menggunakan pendekatan struktural. Data berupa kalimat yang berhubungan dengan masalah yang diteliti yaitu unsur-unsur alur. Sumber data secara tidak langsung adalah penulis cerpen Di Atas Sajadah Cinta karya Habiburrahman El Shirazy. Teknik yang digunakan adalah teknik studi dokumenter. Analisis yang dilakukan peneliti adalah mengenai: pertama, pengenalan situasi cerita (situation). Kedua, pengungkapan peristiwa (generating circumtances). Ketiga, menuju pada adanya konflik (rising action). Keempat, puncak konflik (climax). Kelima, penyelesaian (denouement). Penelitian ini dapat diterapkan sebagai materi ajar dalam pembelajaran bahasa Indonesia di sekolah tingkat SMP/MTs kelas IX semester satu.

Kata Kunci: Analisis, Struktur Alur, Cerpen.

Abstract: The purpose of this study is to describe the plot structure found in Habiburrahman El Shirazy's short story "Di Atas Sajadah Cinta", as well as to apply the plot structure in teaching Indonesian subject in Junior High / MTs Class IX. The study employs descriptive methodology which is qualitative in nature, and takes a structural approach. The plot components become the data in the form of phrases that are connected to the subject being examined. The data comes from Habiburrahman El Shirazy, who is also the author of the short story. The documentary study approach was applied in this case. The following are the results of the research: first, the introduction of narrative circumstances; second, the introduction of story situations; and third, the introduction of tale situations (exposition). Second, there's the issue of complexity. Third, there is an increase in activity. Fourth, the conflict's apex (turning point). The fifth and last point is the conclusion. This study may be used as a teaching tool in Indonesian junior high school / MTs class IX semester 1 classes.

Keywords: Analysis, Plot Structure, Short Stories.
\end{abstract}

Citation: Goffar, A., Wuryantoro, A., \& Ricahyono, S. (2022). Analisis Struktur Alur dalam Cerpen di Atas Sajadah Cinta Karya Habiburrahman El Shirazy. Wewarah: Jurnal Pendidikan Multidisipliner, 1(1), 36 41.

\section{(cc) Br}

Published by Program Pascasarjana Universitas PGRI Madiun. This work is licensed under the Creative Commons AttributionNonCommercial-ShareAlike 4.0 International License. 


\section{PENDAHULUAN}

Alur biasa juga disebut plot merupakan rangkaian peristiwa yang disusunsecara logis dan kronologis, saling berkaitan dan yang diakibatkan atau dialami oleh para pelaku. Aminuddin (1995:83) menyatakan bahwa alur dalamcerpen atau dalam karya fiksi pada umumnya adalah rangkaian cerita yangdibentuk oleh tahapan-tahapan peristiwa sehingga menjalin suatu cerita yang dihadirkan oleh para pelaku dalam suatu cerita. Artinya, suatu peristiwa terjadikarena pasti ada sebab yang ditimbulkan dan kemudian peristiwa tersebut berkaitan dengan peristiwa lainnya.

Dalam sebuah cerita rekaan berbagai peristiwa yang diurutkan itumembangun tulang punggung cerita. Oleh karena itu tidak sedikit orang yangmenganggap alur sebagai unsur terpenting di antara berbagai unsur intrinsiklainnya. Menurut Semi (2012:44) alur dalam sebuah karya sastra memilikikedudukan yang sangat penting karena alur mengatur bagaimana tindakantindakan harus berkaitan satu sama lain. Nurgiantoro (2013:205) juga menyatakan bahwa cerita dan alur merupakan dua unsur fiksi yang amat eratberkaitan sehingga keduanya tidak mungkin dipisahkan karena objek pembicaraanboleh dikatakan sama yakni peristiwa. Selanjutnya Nurgiantoro menjelaskanperbedaan yang sangat terlihat antara cerita danalur. Cerita sekadar mempertanyakan apa atau bagaimana kelanjutan peristiwa, sedangkan alur lebih menekankan permasalahannya pada hubungan kausalitas, kelogisan hubunganantar peristiwa dalam karya naratif yang bersangkutan.

Alur memiliki beberapa struktur. Struktur alur adalah tahapan peristiwa- peristiwa yang terjadi di dalam cerita yang saling berkaitan. Struktur alur dalam karya sastra disusun dengan urutan yaitu pengenalan situasi cerita (situation), pengungkapan peristiwa (generating cicumtances), menuju pada adanya konflik (rising action), puncak konflik (climax), dan penyelesaian (denoument).

Cerpen Di Atas Sajadah Cinta merupakan satu di antara cerpen karya Habiburrahman El Shirazy yang dibungkus dengan alur yang sangat menarik. Cerpen ini menampilkan cerita tentang dua insan manusia yang saling mecintai karena Allah. Zahid adalah seorang pria yang dalam hidupnya selalu berpegang erat kepada benteng Allah, dan selalu menghiasi hidupnya dengan kalimat tasbih. Zahid tak kuasa menangkis pesona seorang gadis jelita yang bernama Afirah. Namun, jalan nasibnya tak semulus yang dia pikirkan. Suatu hari, Zahid telah mantap memutuskan untuk melamar kekasihnya itu. Kedatangannya disambut dengan senyuman yang merekah oleh keluarga gadis itu. Selang waktu kemudian, Zahid pun langsung menyampaikan tujuan kedatangannya, yaitu ingin mengkhitbah Afirah. Dengan jantung yang berdetak begitu kencang, Zahid menunggu jawaban dari pihak Afirah. Seperti menerima peluru yang mematikan, kata"terlambat" itu dilontarkan orang tua Afirah kepada Zahid. Ternyata Afirah telah dikhitbah terlebih dahulu oleh pemuda yang bernama Yasir.

Bak menerima bom yang dahsyat, Zahid dan Afirah terduduk diam dan tak bergairah menerima hal ini. Afirah pun menjadi salah langkah. Ia mengajak Zahid untuk memadu cinta sembunyi-sembunyi. Dengan berlinangan air mata, Zahid menanggapi tawaran Afirah yang gila itu. Zahid menolak tawaran Afirah. Dia mengatakan kepada Afirah bahwa wanita yang tidak baik adalah untuk laki-laki yang tidak baik, dan laki-laki yang tidak baik adalah untuk wanita yanng tidak baik pula, dan sebaliknya. Membaca balasan surat Zahid, Afirah menangis tersedu-sedu. Ia telah menemukan hal yang lebih berharga yaitu hidayah.

Seiring waktu, berita bahagia menghiasi hidup mereka berdua. Zahid menerima surat dari Afirah yang berisikan bahwa ayahnya telah membatalkan pertunangannya dengan Yasir, dan meminta Zahid segera mengkhitbahnya dan menikah dengannya. Setelah membaca surat itu, Zahid segera sujud syukur dan tidak berhenti mengucapkan hamdalah.

Penelitian mengenai struktur alur dilakukan karena unsur alur memiliki peranan sangat penting dalam sebuah cerita. Melalui unsur alur, penelitian ini dapat mengetahui keterkaitan rangkaian suatu peristiwa dengan peristiwa lainnya sehingga cerita tersebut koheren. Rangkaian peristiwa-peristiwa yang terjadi di dalam sebuah cerita tidak dapat berdiri sendiri, yang satu terlepas dari yang lain, melainkan merupakan peristiwa-peristiwa yang saling berkaitan. Hal inilah yang peneliti kaji dalam cerpen Di Atas Sajadah Cinta karya Habiburrahman El Shirazy, yakni keterkaitan antar peristiwa satu dengan yang lainnya sehingga cerpen tersebut lebih mudah dipahami. Dikaitkan materi Bahasa Indonesia dengan Kurikulum 2013 Permen No.24 Tahun 2016 di SMP kelas IX semester 1 terhadap analisis struktur alur dalam cerpen Di Atas Sajadah Cinta 
karya Habiburrahman El Shirazy, hal tersebut sesuai dengan KI 3: Memahami pengetahuan (faktual, konseptual,dan prosedural) berdasarkan rasa ingin tahunya tentang ilmu pengetahuan, teknologi, seni, budaya terkait fenomena dan kejadian tampak mata. Kompetensi Dasar 3.5: Mengidentifikasi unsur pembangun karya sastra dalam teks cerita pendek yang dibaca atau didengar dan KD 4.5 Menyimpulkan unsur-unsur pembangun karya sastra dengan bukti yang mendukung dari cerita pendek yang dibaca atau didengar.

\section{METODE}

Metode yang digunakan dalam penelitian ini adalah metode deskriptif. Metode deskriptif adalah metode yang memberikan gambaran atau penjelasan suatu objek sehingga dapat diketahui kondisi subjek atau objek secara jelas dan sesuai dengan fakta yang ada. Menurut Jauhari (2010:34) metode deskriptif tidak hanya menggambarkan keadaan subjek atau objek penelitian berdasarkan faktafakta yang ada tetapi juga menganalisis subjek atau objek penelitian. Moleong (2006:4) juga menyatakan metode deskriptif digunakan untuk memberikan gambaran mengenai analisis data yang berupa kata-kata serta gambar-gambar tetapi tidak termasuk angka. Dengan demikian penggunaan metode ini dalampenelitian dapat memberikan gambaran dan memaparkan kutipan-kutipan bagian dari struktur alur dalam cerpen Di Atas Sajadah Cinta karya Habiburrahman El Shirazy.

Bentuk penelitian ini adalah penelitian kualitatif. Bentuk penelitian kualitatif digunakan karena data dianalisis satu persatu, apa adanya sesuai dengan sifat data yang alamiah. Analisis struktur alur dalam cerpen Di Atas Sajadah Cinta dikaji dan diuraikan dalam bentuk kata-kata maupun kalimat dan tidak dalam bentuk angka-angka maupun mengadakan perhitungan. Pendekatan penelitian yang digunakan dalam penelitian ini adalah pendekatanstruktural. Kajian pendekatan struktural menitikberatkan pada unsur intrinsik karya sastra. Teeuw (dalam Rafiek 2012: 32) mengatakan bahwa pendekatanstruktural mencoba menguraikan keterkaitan dan fungsi masing-masing unsurkarya sastra sebagai kesatuan struktural yang bersama-sama menghasilkan makna menyeluruh. Sehingga pendekatan ini dilakukan dengan mengklasifikasikan dan mendeskripsikan struktur alur dalam cerpen Di Atas Sajadah Cinta karya Habiburrahman El Shirazy

Sumber data dalam penelitian ini adalah cerpen Di Atas Sajadah Cinta karya Habiburrahman El Shirazy yang diterbitkan oleh Republika Penerbit, 2020.

Data dalam penelitian ini adalah berupa kata-kata, frasa, maupun kalimatyang berhubungan dengan masalah yang diteliti, yakni kutipan yang mengambarkan struktur alur yang meliputi pengenalan situasi cerita (exsposition), pengungkapan peristiwa (complitation), menuju pada adanya konflik (rising action), puncak konflik (turning point), dan penyelesaian (ending) yang terdapat dalam cerpen Di Atas Sajadah Cinta karya Habiburrahman El Shirazy.

Teknik pengumpulan data menjadi hal yang penting untuk dilakukan. Saat melakukan penelitian, harus mengetahui terlebih dahulu teknik yang digunakan sehingga dapat mempermudah dalam proses pengumpulan data. Teknik pengumpulan data dalam penelitian ini adalah teknik studi dokumenter atau tekniktidak langsung. Teknik ini digunakan karena peneliti berusaha menganalisis dokumen yaitu cerpen Di Atas Sajadah Cinta karya Habiburrahman El Shirazy, untuk mengetahui stuktur alur cerpen tersebut.

Alat pengumpulan data dalam penelitian ini adalah manusia atau penelitidan kartu pencatat. Peneliti sebagai instrument kunci, yaitu merupakan perencana,pelaksana, pengumpul data, penganalisis data, penafsir data, dan pada akhirnya menjadi pelapor hasil penelitian. Peneliti menggunakan kartu pencatat atau kertas pencatat untuk mencatat dari hasil pembacaan dan pengamatan terhadap cerpen Di Atas Sajadah Cinta karya Habiburrahman El Shirazy. Catatancatatan yang berupa data selanjutnya dihimpun secara khusus menurut klasifikasi permasalahan penelitian. Data yang dianalisis perlu dilakukan pengujian keabsahannya, hal ini dimaksudkan agar peneliti mendapatkan hasil yang objektif. Untuk mendapatkan keabsahan data, ada tiga cara yang digunakan yaitu: (1) ketekunan pengamatan, (2) triangulasi penyidik, (3) kecukupan referensi.

\section{HASIL PENELITIAN}

Penelitian yang dilakukan peneliti menghasilkan stuktur alur yang meliputi pengenalan situasi cerita 
(situation), pengungkapan peristiwa(generating circumstance), menuju pada adanya konflik (rising action), puncak konflik (climax), dan penyelesaian (denoument). Kedua, implementasi penelitian terhadap pembelajaran bahasa Indonesia di SMP/MTS kelas IX. Berdasarkan analisis yang telah dilakukan, berikut isi simpulan yang dapat diambil dalam penelitian ini.

Pengenalan situasi cerita (situation) yang terdapat dalam cerpen Di Atas Sajadah Cinta karya Habiburrahman El Shirazy meliputi: pengenalan tokoh-tokoh, pengenalan situasi, danpengenalan adegan cerita. Hal tersebut diawali dengan seorang pemuda bernama Zahid berdiri tegap menghadap kiblat di serambi masjid Kufah. Sebagian besar waktunya dihabiskan di masjid untuk ibadah dan menuntut ilmu pada ulama terkemuka di Kufah. Saat itu masjid sebagai pusat peradaban, pusat pendidikan, pusat informasi dan pusat perhatian (El Zhirazy:2020:1). Pemuda itu terus larut dalam samudra ayat Ilahi. Setiap kali sampai ayat-ayat azab, tubuh pemuda itu bergetar hebat. Air matanya mengalir deras. Namun jika ia sapai ayat-ayat nikmat dan surga, ia merasakan kesejukan dan kebahagiaan (El Zhirazy:2020:1). Di pinggir kota tampak rumah mewah milik saudagar kaya memiliki kebun kurma yang luas dan banyak hewan ternak. Dalam kamarnya, tampak gadis jelita sedang menari-nari riang gembira mendendangkan syair-syair cinta (El Zhirazy:2020:3).

Pengungkapan peristiwa (generating circumstances) yang terdapat dalam cerpen Di Atas Sajadah Cinta karya Habiburrahman El Shirazy meliputi: peristiwa awal yang menimbulkan berbagai masalah dan kesukaran-kesukaran bagi para tokohnya. Hal itu ditunjukan dengan keadaan di ruang tengah, kedua orang tuanya menyungging senyum mendengar syair yang didendangkan Afirah sebagi tanda saatnya menikah. Saat di pasar, ibu Afirah berjumpa ayah Yasir melamar Afirah untuk putranya Yasir(El Zhirazy:2020:3). Orang tua Afirah menerima lamaran Yasir tanpa persetujuan putrinya (El Zhirazy:2020:3).

Menuju pada adanya konflik ( rising action) yang terdapat dalam cerpen Di Atas Sajadah Cinta karya Habiburrahman El Shirazy meliputi: kehebohan ataupun keterlibatan berbagai situasi yang menyebabkan kesukaran tokoh. Hal tersebut diawali Zahid hendak menjenguk saudaranya yang sakit. Di tengah melewati kebun kurma yang luas, dia menjumpai perempuan penunggang kuda berlari kencang minta tolong untuk menghentikan kudanya. Kuda berhenti seketika, perempuan (gadis bernama Afirah) itu jatuh terpelanting. Afirah berkenalan dengan Zahid sebagai tanda sapu tangan hijau. Afirah terpekur di kamarnya jatuh hati kepada Zahid, (El Zhirazy:2020:79).

Puncak konflik (climax) yang terdapat dalam cerpen Di Atas Sajadah Cinta karya Habiburrahman El Shirazy meliputi: ditentukannya perubahan nasib beberapa tokoh apakah dia berhasil atau gagal menyelesaikan masalahnya. Hal tersebut ditunjukkan dengan Zahid di dalam masjid Kufah, hatinya dipenuhi gelora cinta terus ia paksa untuk menepis noda nafsu. Rasa cintanya pada Tuhan. Rasa takut akan azab-Nya. Rasa cinta dan rindunya pada Afirah. Semuanya bercampur dalam puncak munajatnya, ia pingsan. Usai salat Dhuha Zahid melamar Afirah. Lamaran Zahid ditolak karena Afirah sudah dilamar Abu Yasir. Zahid jatuh sakit. Kabar derita Zahid tersebar seantero Kota Kufah. Afirah menulis surat untuk Zahid menawarkan hal untuk mengobati rasa haus cinta berdua. Zahid menulis balasan surat Afirah menolak tawaran, (El Zhirazy:2020:9-14).

Penyelesaian (denoument) yang terdapat dalam cerpen Di Atas Sajadah Cinta karya Habiburrahman El Shirazy meliputi: penjelasan tentang nasib-nasib yang dialami tokohnya setelah mengalami peristiwa puncak. Hal tersebut ditunjukkan dengan Afirah setelah membaca balasan surat Zahid menjadi insaf berubah gaya hidupnya. Sorban putih pemberian Zahid dijadikannya sajadah. Di atas sajadah putih itu ia menemukan cinta kepada Allah Swt. (El Zhirazy:2020:14). Beberapa bulan kemudian Zahid menerima sepucuk surat dari Afirah untuk datang melamarnya karena ayah Afirah sudah memutuskan tali pertunangan dengan Yasir ( El Zhirazy:2020:15).

\section{PEMBAHASAN}

Penelitian bertujuan untuk menganalisis struktur alur yang terdapat dalam cerpen Di Atas Sajadah Cinta karya Habiburrahman El Shirazy. Ringkasan hasilnya pertama, pengenalan situasi cerita (situation) yang terdapat dalam cerpen Di Atas Sajadah Cinta karya Habiburrahman El Shirazy meliputi pengenalan tokoh-tokoh, pengenalan situasi, dan pengenalan adegan. Kedua, pengungkapan peristiwa (generating circumtances) yang terdapatdalam cerpen Di Atas Sajadah Cinta karya Habiburrahman El Shirazy meliputi peristiwa awal yang menimbulkan berbagai masalah dan kesukaran-kesukaran bagi para tokohnya. Ketiga, menuju pada adanya konflik ( rising Wewarah 
action) yang terdapat dalam cerpen Di Atas Sajadah Cinta karya Habiburrahman El Shirazy meliputi kehebohan ataupun keterlibatan berbagai situasi yang menyebabkan kesukaran tokoh. Keempat, puncak konflik (climax) yang terdapat dalam cerpen Di Atas Sajadah Cinta karya Habiburrahman El Shirazy meliputi ditentukannya perubahan nasib beberapa tokoh apakah dia berhasil atau gagal menyelesaikan masalahnya. Kelima, penyelesaian (denoument) yang terdapat dalam cerpen Di Atas Sajadah Cinta karya Habiburrahman El Shirazy meliputi penjelasan tentang nasib-nasib yang dialami tokohnya setelah mengalami peristiwa puncak.

Hasil penelitian dengan 5 elemen alur pada penelitian ini sejalan dengan penelitian "Analisis Struktur Alur dalam Novel 'Tapak Jejak' Karya Fiersa Besari” oleh Oktaviani, Priyadi, dan Wartiningsih yang juga menemukan 5 unsur dalam alurnya (2021). Penelitian oleh Riyadi, Priyadi, dan Seli "Analisis Struktur Alur dalam Novel Pergolakan Karya Wildan Yatim" juga menemukan hal yang sama, 5 unsur alur dalam novel tersebut (2017). Penelitian "Analisis Struktur Intrinsik pada Novel 'Byar-Byur Ring Pesisi Sanur' Karya Nyoman" oleh Dewi dan Jayawangsa menemukan jenis alur lurus atau progresif sehingga juga sejalan dengan hasil penelitin ini (2021).

Akan tetapi hasil penelitian ini berbeda dengan penelitian "Analisis Struktur Alur dalam Novel Ayat-Ayat Cinta 2 Karya Habiburrahman El Shirazy" oleh Idrus, Martono, dan Wartiningsih. Di dalam penelitian itu ditemukan struktur alur terdiri dari 4, bukan 5 bagian (2021). Saina, Syamsiyah, dan Riko melakukan penelitian "Analisis Struktur dalam Novel "Seperti Hujan Yang Jatuh Ke Bumi "Karya Boy Candra" menemukan jenis alur campuran yang berbeda dengan temuan penelitian ini (2020).

\section{SIMPULAN DAN SARAN}

\section{Simpulan}

Berdasarkan analisis data dapat simpulkan bahwa struktur alur yang terdapat dalam cerpen Di Atas Sajadah Cinta karya Habiburrahman El Shirazy adalah sebagai berikut: (1) pengenalan situasi cerita (situation) yang terdapat dalam cerpen Di Atas Sajadah Cinta karya Habiburrahman El Shirazy meliputi pengenalan tokoh-tokoh, pengenalan situasi, dan pengenalan adegan. (2) pengungkapan peristiwa (generating circumtances) yang terdapatdalam cerpen Di Atas Sajadah Cinta karya Habiburrahman El Shirazy meliputi peristiwa awal yang menimbulkan berbagai masalah dan kesukaran-kesukaran bagi para tokohnya. (3) menuju pada adanya konflik ( rising action) yang terdapat dalam cerpen Di Atas Sajadah Cinta karya Habiburrahman El Shirazy meliputi kehebohan ataupun keterlibatan berbagai situasi yang menyebabkan kesukaran tokoh. (4) puncak konflik (climax) yang terdapat dalam cerpen Di Atas Sajadah Cinta karya Habiburrahman El Shirazy meliputi ditentukannya perubahan nasib beberapa tokoh apakah dia berhasil atau gagal menyelesaikan masalahnya. (5) penyelesaian (denoument) yang terdapat dalam cerpen Di Atas Sajadah Cinta karya Habiburrahman El Shirazy meliputi penjelasan tentang nasib-nasib yang dialami tokohnya setelah mengalami peristiwa puncak.

\section{Saran}

Berdasarkan penelitian yang telah dilakukan saran peneliti sebagai berikut: (1) hasil penelitian ini dapat dijadikan rujukan oleh guru bahasa Indonesiauntuk mengajarkan materi pembelajaran sastra khususnya struktur alur cerpen, (2) cerpen Di Atas Sajadah Cinta karya Habiburrahman El Shirazy dapat dijadikan bahan bacaan bagi pembaca karya sastra, dan (3) penelitian ini dapat dijadikan perbandingan untuk peneliti-peneliti lain. Selain itu, peneliti lain dapat menjadikan cerpen $D i$ Atas Sajadah Cinta karya Habiburrahman El Shirazy sebagai suatu objek penelitian lebih lanjut atau berkaitan dengan aspek yang berbeda. 


\section{DAFTAR PUSTAKA}

Abidin, Yunus. 2012. Pembelajaran Bahasa Berbasis Pendidikan Karakter.Bandung: Refika Aditama.

Albertus, Doni Koesoema. 2010. Pendidikan Karakter: Strategi Membangun Anak di Zaman Global. Jakarta: Gramedia Widiasarana Indonesia.

Aminudin. 1995. Apresiasi Karya Sastra. Bandung: Sinar Baru Algesindo.

B.Miles,Matthew.A Michel Huberman.2014. Analisis Data Kualitatif (Terjemah : Tjetjep Rohendi Rohidi) Jakarta : Universitas Indonesia

Dewi, N. P. E. A. S. R., \& Jayawangsa, I. G. A. R. (2021). ANALISIS STRUKTUR INTRINSIK PADA NOVEL BYAR-BYUR RING PESISI SANUR KARYA NYOMAN. Subasita: Jurnal Sastra Agama Dan Pendidikan Bahasa Bali, 2(1), Article 1. http://jurnal.stahnmpukuturan.ac.id/index.php/subasita/article/view/1414

Endraswara, Suwardi. 2011. Metodologi Penelitian Sastra. Yogyakarta: CAPS.

El Shirazy, Habiburrahman. 2013. Catatan Motivasi Seorang Santri. Semarang : Publishing House.

.....2020. Di Atas Sajadah Cinta. Jakarta : Rebuplika Penerbit.

Fahmi. 2014. "Analisis Struktur Alur Novel ORB Karya Galang Lufityanto". Skripsi. Jakarta: UIN Syarif Hidayatullah.

Febrianus, Yuven. 2016. "Analisis Alur dalam Roman Jejak Langkah karya Pramoedya Ananta Toer”. Skripsi. Pontianak: FKIP Untan.

Hartoko, Dick dan B. Rahmanto. 1985. Pemandu di Dunia Sastra. Yogyakarta: Kanisius. Jabrohim.2012. Teori Penelitian Sastra. Yogyakarta: Pustaka Pelajar.

Kokasih E. 2012. Dasar-Dasar Keterampilan Bersastra. Bandung: Yrama Widya.

Moleong, Lexy J.2006. Metodologi Penelitian Kualitatif. Bandung: Remaja Rosdakarya.

Nurgiyantoro, Burhan. 2013. Teori Pengkajian Fiksi.Yogyakarta: Gadjah Mada University Press.

Oktaviani, O., Priyadi, A. T., \& Wartiningsih, A. (2021). ANALISIS STRUKTUR ALUR DALAM NOVEL TAPAK JEJAK KARYA FIERSA BESARI. Jurnal Pendidikan Dan Pembelajaran Khatulistiwa, 10(3), Article 3. https://jurnal.untan.ac.id/index.php/jpdpb/article/view/45938

Ratna, Nyoman Kutha. (2011). Teori, Metode, dan Teknik Penelitian Sastra.Yogyakarta: Pustaka Pelajar.

Rafiek, M. 2012. Teori Sastra. Bandung: PT Refika Aditama.

Riyadi, I., Priyadi, T., \& Seli, S. (2017). ANALISIS STRUKTUR ALUR DALAM NOVEL PERGOLAKAN KARYA WILDAN YATIM. Jurnal Pendidikan Dan Pembelajaran Khatulistiwa, 6(2), Article 2. https://jurnal.untan.ac.id/index.php/jpdpb/article/view/18674

Saina, E., Syamsiyah, S., \& Riko, R. (2020). ANALISIS STRUKTUR DALAM NOVEL "SEPERTI HUJAN YANG JATUH KE BUMI "KARYA BOY CANDRA. Jurnal Pendidikan Bahasa dan Sastra Indonesia Metalingua, 5(1), 7-14. https://doi.org/10.21107/metalingua.v5i1.6523

Semi, M. Atar .2012. Metode Penelitian Sastra. Bandung: CV Angkasa.

Tarigan, Henry Guntur. 1984. Prinsip-Prinsip Dasar Sastra. Bandung: Angkasa.

Wellek Rene dan Austin Warren, 2014. Teori Kesusastraan. Jakarta: Gramedia.

Yatim, Wildan. 1999. Pergolakan. Jakarta: PT Grasindo.

Zaidan, A. R, Anita, K. R dan Hani'ah, 2004. Kamus Istilah Sastra. Jakarta: BalaiPustaka. 